ScIDice

\section{Comparative Evaluation of Glutraldehyde, UV Radiation, Herbal and Autoclave for Disinfection of Impression Materials}

Research Article

Amiya Ranjan Sahoo ${ }^{1}$, Piyush Oswal ${ }^{2}$, Kyatsandra Narasimhaiah Jagadeesh ${ }^{3 *}$, Prasanna Turuvekere Ramaiah ${ }^{4}$

${ }^{1}$ Senior Lecturer, Department of Oral Surgery, Awadh dental college, Jamshedpur, Jharkand, India.

${ }^{2}$ Associate Professor, Department of Conservative Dentistry \& Endodontics, Dr. DY Patil Dental College and Hospital, Dr. DY Patil Vidyapeeth, Pune, Maharastra, India..

${ }^{3}$ Professor, Department of Prosthodontics, Sri Siddhartha Dental College, Sri Siddhartha Academy of Higher Education, Tumkur, Karnataka, India.

${ }^{4}$ Professor and HOD, Department of Orthodontics, Sri Siddhartha Dental College, Sri Siddhartha Academy of Higher education, Tumkur, Karnataka, India.

\title{
Abstract
}

Background: There is a chance of cross infection between dental clinics and dental laboratories with contaminated impression materials.

Objectives: The present study was conducted to compare glutraldehyde, UV radiation, herbal and autoclave method of disinfection of impression materials.

Materials \& Methods: The present study was conducted in the department of Prosthodontic. It comprised of 40 alginate impression materials which were disinfectant with $2.2 \%$ glutraldehyde, UV radiation, herbal product and autoclave. The pre and post bacterial count was assessed.

Results: The mean pre microbial contamination in group I was 366.1, in group II was 302.7, in group III was 345.8 and in group IV was 338.4. One-way ANOVA test was applied which revealed non- significant difference (P>0.05) in CFU in all groups. The mean post microbial contamination in group I was 68.1, in group II was 74.2, in group III was 125.3 and in group IV was 26.8 . Maximum reduction was observed in group IV, followed by group I, II and III. One-way ANOVA test was applied which revealed significant difference $(\mathrm{P}<0.05)$ in $\mathrm{CFU}$ in all groups.

Conclusion: Authors found that autoclave is the better method of sterilization compared to use of glutraldehyde, UV radiation and herbal disinfectant.

Keywords: Autoclave; Glutraldehyde; Sterilization; UV Radiation.

\section{Introduction}

Impression materials are frequently contaminated with oral fluid such as saliva and blood. Person dealing with this impression material is prone to get infected if not handled carefully. There is chance of cross infection between dental clinics and dental laboratories [1]. Studies have demonstrated that contaminated impressions can cross infect gypsum casts that were poured against them. There have been numerous methods for disinfection of impression materials. Rinsing with water was the easiest and frequently used method. Suggestion by Guidelines for infection control in dental health care include that cleaning, disinfection, and rinsing of all dental prostheses and prosthodontic items should be done before they are handling in the laboratory using an active hospital disinfectant [2].

There are several disinfection methods such as soaking in chemical disinfectant, autoclave, radiation, herbal etc [3]. The disinfectant solution should show greater efficacy in the reduction of pathogenic microorganisms without interfering with the dimensional stability or ability to replicate particulars of the material. Unlike disinfection, sterilization is a procedure that eliminats all microorganisms. Sterilization is a preferred method of cross-infection control in the dental clinics [4].

Disinfection is categorized into three categories such as high level

*Corresponding Author:

Dr. Kyatsandra Narasimhaiah Jagadeesh,

Professor, Department of Prosthodontics, Sri Siddhartha Dental College, Sri Siddhartha Academy of Higher Education, Tumkur, Karnataka, India.

E-mail: jagadeeshmds1976@gmail.com

Received: October 20, 2020

Accepted: November 01, 2020

Published: November 07, 2020

Citation: Amiya Ranjan Sahoo, Piyush Oswal, Kyatsandra Narasimhaiah Jagadeesh, Prasanna Turuvekere Ramaiah. Comparative Evaluation of Glutraldehyde, UV Radiation, Herbal and Autoclave for Disinfection of Impression Materials. Int J Dentistry Oral Sci. 2020;S2:02:006:21-23. doi: http://dx.doi.org/10.19070/2377-8075-SI02-02006

Copyright: Kyatsandra Narasimhaiah Jagadeesh ${ }^{\circ} 2020$. This is an open-access article distributed under the terms of the Creative Commons Attribution License, which permits unrestricted use, distribution and reproduction in any medium, provided the original author and source are credited. 
disinfection, which includes bacterial spore and other microbial forms inactivity, intermediate level disinfection includes, destruction of microorganisms like tubercle bacilli and low level disinfection possesses narrow antimicrobial activity [5]. The present study was conducted to compare glutraldehyde, UV radiation, herbal and autoclave method of disinfection of impression materials.

\section{Materials and Methods}

The present study was performed in the department of Prosthodontics. It comprised of 40 alginate impression materials. The ethical approval was obtained from, institutional ethics committee. The study was done by single trained investigator.

Four groups were made. In group I, impression material was disinfected with $2.2 \%$ glutraldehyde (chemical agent for $5 \mathrm{~min}$ ), in group II with radiation ( for $20 \mathrm{~min}$ ), group III with herbal product $(E \operatorname{cosan} \circledast$ for $10 \mathrm{~min})$ and group IV was sterilized with autoclave.

Following, disinfection and autoclaving, all the impressions were subjected for microbial assessment. To obtain the growth of micro-organisms, nutrient agar was used as a media. Pour plate technique was employed to equally dispense the diluted samples on the Petri plates containing the nutrient agar. These Petri plates were then inoculated and incubated at $37^{\circ} \mathrm{C}$ for $24 \mathrm{~h}$. Total number of colony forming units (CFU's) of the viable micro-organisms following incubation were examined and recorded using a digital colony counter on petri dish. The pre disinfectant count was compared with post disinfectant count.
The result thus obtained was assessed using SPSS version 20 (IBM. Chicago, USA). The total viable count was expressed as mean and standard deviation (SD). One-way ANOVA and t test was used to compare pre and post disinfectant $\mathrm{CFU}$ in all groups with $\mathrm{p}$ value significance at 0.05 .

\section{Results}

Mean pre microbial contamination in group I was 366.1, in group II was 302.7, in group III was 345.8 and in group IV was 338.4 $(\mathrm{P}>0.05)$ in $\mathrm{CFU}$ in all groups. Mean post microbial contamination in group I was 68.1, in group II was 74.2, in group III was 125.3 and in group IV was 26.8. One-way ANOVA test was applied which revealed significant difference $(\mathrm{P}<0.05)$ in $\mathrm{CFU}$ in all groups (Table-1).

Table 2 shows that there was significant difference in pre and post microbial CFI in all groups. Maximum reduction was observed in group IV, followed by group I, II and III. One-way ANOVA test was applied which revealed significant difference $(\mathrm{P}<0.05)$ in CFU in all groups.

\section{Discussion}

Cross infection control is the most significant and relevant topic among health care workers. Cross infection is the transition of an infectious cause from one individual to another in a clinical condition [6]. Over past 22 years, new infectious diseases have been observed at a rate of one disease per year. Infection transmission may be seen while taking impression with different impression material. Dental staff including hygienists is at higher risk to get-

Table 1. Pre-Disinfection Microbial Contamination.

\begin{tabular}{|c|c|c|}
\hline Groups & Mean (106 CFU/ml) & P value \\
\hline Pre-disinfection & & \\
\hline Group I & 366.1 & 0.081 \\
\hline Group II & 302.7 & \\
\hline Group III & 345.8 & \\
\hline Group IV & 338.4 & \\
\hline Post-disinfection & & \\
\hline Group I & 68.1 & 0.001 \\
\hline Group II & 74.2 & \\
\hline Group III & 125.3 & \\
\hline Group IV & 26.8 & \\
\hline
\end{tabular}

One-way ANOVA, $\mathrm{p}<0.05$, significant

Table 2. Comparison of the pre- and post-disinfection microbial contamination in different groups.

\begin{tabular}{|c|c|c|c|c|c|}
\hline Groups & Pre & Post & t & df & P \\
\hline Group I & 366.1 & 68.1 & 12.81 & 2 & 0.012 \\
\hline Group II & 302.7 & 74.2 & 11.36 & 2 & 0.057 \\
\hline Group III & 345.8 & 125.3 & 10.91 & 2 & 0.024 \\
\hline Group IV & 338.4 & 26.8 & 13.15 & 2 & 0.001 \\
\hline
\end{tabular}

One-way ANOVA, $\mathrm{p}<0.05$, significant 
ting exposed to infectious agents such as AIDS, hepatitis, herpes simplex and cytomegalo virus etc [7].

It has been studied that approximately 300-400 million people are chronic hepatitis B carriers worldwide [8]. For dental practitioners, transmission of hepatitis virus is the major occupational hazards. Moreover, HIV can be transmitted by transfusions, needle stick injury or contact of mucous membrane with the blood or body fluids of a carrier. Dentists are very prone to such detriments due to their nature of work. Thus it becomes necessary to follow disinfectants and sterilization procedure [9]. The present study was conducted to compare glutraldehyde, radiation, herbal and autoclave method of disinfection of impression materials.

We found that mean pre microbial contamination in group I was $366.1 \mathrm{X} 106$, in group II was 302.7 X 106, in group III was 345.8 X 106 and in group IV was 338.4 X 106. Ganavadiya et al assessed the reduction in total viable count using different disinfectants; $6 \%$ hydrogen peroxide $\left(\mathrm{H}_{2} \mathrm{O}_{2}\right) 2 \%$ glutaraldehyde, and autoclaving as a positive control. It was found that autoclaved instruments resulted in complete elimination of viable micro-organisms. In descending order $\mathrm{H}_{2} \mathrm{O}_{2}$ group showed maximum reduction in microbial load followed by glutaraldehyde, ethyl alcohol and distilled water. Microbial contamination was recorded maximum on locally manufactured mirrors, over standard plain mirrors [10].

We observed that mean post microbial contamination in group I was $68.1 \mathrm{X} 106$, in group II was 74.2 X 106, in group III was 125.3 $\mathrm{X} 106$ and in group IV was $26.8 \mathrm{X} 106$. Jha et al in their study assessed the antimicrobial efficiency of an organic disinfectant Ecosan ${ }^{\circledR}$ over only rinsing with water for alginate impression material after oral contact. Impression region was sliced up in the first permanent molar and second deciduous molar region into two portions. After inoculation in nutrient media, the microbial colony was counted and compared for both groups. There was significant reduction in bacterial count in area sterilized with Ecosan ${ }^{\circledR}$ as compared to water [11].

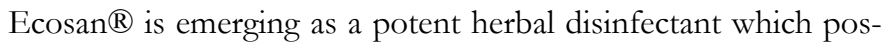
sess characteristic and structure of honey with primary active ingredient as natural polymer of glucosamine. The presence of quaternary ammonium compound is used as an emulsifying agent. The natural anthraquinones in the form of aloin from Aloe Vera also boosts its antimicrobial property. This natural polymer of glucosamine in combination with Aloe Vera has bioactive properties, wound healing, haemostatic, and tissue regeneration [12].

Samra and Bhide evaluated the different disinfectants (glutaraldehyde, sodium hypochlorite and ultraviolet chamberon) on impression material (alginate and addition silicone of native origin) and found good result for dimensional stability and acceptable disinfection using ultra violet chamber and sodium hypochlorite disinfection method [13].
$2.2 \%$ glutraldehyde can be used as a chemical means of sterilization alternative to autoclave method for impression material which doesn't cause much dimensional changes, but autoclaving is the best method for sterilization.

The limitations of the study are the smaller sample size using fewer disinfectants. Further studies are required to evaluate on larger sample size with different disinfecting agents.

\section{Conclusion}

This study found that autoclave is the better method of sterilization of impression material compared to use of glutraldehyde, UV radiation and herbal disinfectant.

\section{References}

[1]. Maller SV, Karthik KS, Maller US, Abraham MC, Kumar RN, Manikandan R. Drug and dental impression materials. J Pharm Bioallied Sci. 2012 Aug;4(Suppl 2): S316-S318.

[2]. Demajo JK, Cassar V, Farrugia C, Millan-Sango D, Sammut C, Valdramidis $\mathrm{V}$, et al. Effectiveness of Disinfectants on Antimicrobial and Physical Properties of Dental Impression Materials. Int J Prosthodont. 2016;29(1):63.

[3]. Chidambaranathan AS, Balasubramanium M. Comprehensive Review and Comparison of the Disinfection Techniques Currently Available in the Literature. J Prosthodont. 2017 Apr 19:1-8.Pubmed PMID: 28422353.

[4]. Khinnavar PK, Kumar BH, Nandeeshwar DB. An in vitro study to evaluate the effect on dimensional changes of elastomers during cold sterilization. J Indian Prosthodont Soc. 2015 Apr-Jun;15(2):131-7.Pubmed PMID: 26929499.

[5]. Nassar U, Chow AK. Surface Detail Reproduction and Effect of Disinfectant and Long-Term Storage on the Dimensional Stability of a Novel Vinyl Polyether Silicone Impression Material. J Prosthodont. 2015 Aug;24(6):494-8. Pubmed PMID: 25522249.

[6]. Godbole SR, Dahane TM, Patidar NA, Nimonkar SV. Evaluation of the Effect of Ultraviolet Disinfection on Dimensional Stability of the Polyvinyl Silioxane Impressions. an in-Vitro Study. J Clin Diagn Res. 2015 Sep;8(9):73-76.

[7]. Badrian H, Davoudi A, Molazem M, Zare MH. The effect of spraying different disinfectants on condensational silicone impressions; an in vitro study. J Indian Prosthodont Soc. 2015 Jul-Sep;15(3):263-7.Pubmed PMID: 26929523.

[8]. Aeran H, Sharma S, Kumar V, Gupta N. Use of Clinical UV Chamber to Disinfect Dental Impressions: A Comparative Study. J Clin Diagn Res. 2015 Aug;9(8):ZC67-70.Pubmed PMID: 26436051.

[9]. Al Mortadi N, Al-Khatib A, Alzoubi KH, Khabour OF. Disinfection of dental impressions: knowledge and practice among dental technicians. Clin Cosmet Investig Dent.2019;11:103.-108.

[10]. Ganavadiya R, Chandra Shekar BR, Saxena V, Tomar P, Gupta R, Khandelwal G. Disinfecting efficacy of three chemical disinfectants on contaminated diagnostic instruments: A randomized trial. J Basic Clin Pharm. 2014 Sep;5(4):98-104.Pubmed PMID: 25316989.

[11]. Jha P, Shetty AK, Anandakrishna L. Efficiency of an organic disinfectant on alginate impressions-A Pilot Study. JDOR.2019;17(18):19-20.

[12]. Sahar Elkholy and Walid lofty. Sacred Lotus as an impression disinfectant and its effect on the dimensional stability of an elastomeric impression material. Acta sci. dent. sci.2018:39-44.

[13]. Samra RK, Bhide SV. Comparative evaluation of dimensional stability of impression materials from developing countries and developed countries after disinfection with different immersion disinfectant systems and ultraviolet chamber. Saudi Dent J. 2018 Apr;30(2):125-141.Pubmed PMID: 29628736. 